\title{
日本の海洋観測・探査のための調査船等運航ネットワーク
}

國本 志帆 ${ }^{1} \cdot$ 林 祐司 $^{2}$

\section{Construction of Network of Research and Training Vessels for Ocean Observation and Exploration in Japan}

\author{
Shiho KUNIMOTO and Yuji HAYASHI
}

\begin{abstract}
Total area of Japanese territorial waters and exclusive economic zone (EEZ) is the sixth largest in the world. As compared with such vast sea area, Japan has been operating insufficient number of vessels and voyages for getting required data of observation and exploration in the ocean of Japanese present situation. On the other hand, the organization University-National Oceanographic Laboratory System (UNOLS) ${ }^{(1)}$ in North America, has been operating systematic 18 survey vessels of four organizations (March, 2016), Therefore, ocean observation and exploration of the Pacific Ocean and the Atlantic Ocean has been advanced steadily.

In order to steady research of ocean observation and exploration in Japan, Japanese research vessel and training ship (research vessels) belonging to national and public institutions will be good used. They have ability for ocean research and exploration potentially, and it is necessary to build up their network for smooth assignment of the research vessels. We authors propose to create database about them to understand the performance of such research vessels, crew, regular quay, operational performance and operating environment, etc., and discuss research vessels operating network.
\end{abstract}

Keywords: global environment, ocean observation and exploration, database of research and training vessels, network of research and training vessels

キーワード: 地球環境、海洋観測・探查、調查船等運航データベース、調查船等運航ネットワーク

\section{1. はじめに}

日本の領海および EEZ の総面積は、約 447 万 $\mathrm{km}^{2}$ であり、当該水域の海洋底には多くの鉱物資源等の 存在が期待されている。それに対して日本の現状は、 国立研究開発法人海洋研究開発機構 (JAMSTEC) を中 心に海洋観測や海洋底探査が行われているが、その 状況をより進捗させるためには、調査や掘削を支援 するための全国規模の体制が必要である。そのため に、日本国内の国公立機関が所有する調查船等 (102 隻 ; 2016 年 7 月現在）を本来業務以外の期間に効率
よく海洋観測・探査や学術研究のために運航するこ とを提案する。

本研究は、アメリカにおいて 1971 年に発足し、 調査船 18 隻を 58 の研究機関で共同運航している UNOLS (University-National Oceanographic Laboratory System)を一つの例とし、日本国内の公 立機関が保有する調査船等運航ネットワークを構築 することを目的とする。そのために、「船舶」、「乗組 員」、「係留施設」、「運航実績」等の調查船等データ ベースを作成し、現状で何が存在し、何が不足して 
いるかを分析して、円滑な海洋観測・探査を実現す るための調査船等運航ネットワーク構築に関する提 案を行う。

\section{2. 研究方法}

潜在的に海洋観測・探查能力を保有寸る総トン数 100 トン以上の国公立機関所有調査船等は現時点で 102 隻存在する。

本論文における「調查船等」については、その具 体を明記するために運航目的や海洋調查対象につい て以下の船舶を対象とする。

(1) 海技者・水産技術者教育のための練習船（海洋 観測設備を持つ。）例えば水産高等学校の所有船が ある。

(2) 同上（海洋観測設備を持たない。）例えば商船系 練習船がある。

(3)海洋調查船（気象観測を主とする設備を持つ。）

(4) 海洋調査船（音波や地磁気による、海中や海底 探查を主とする。)

（5）海洋調查船（採水、CTD (Conductivity Temperature Depth profiler; 電気伝導度による海 水観測装置)、プランクトンネット等で海水・水中 生物分析を主とする。）例えば水産試験場の所有船 がある。

(6)海洋調查船（ドレッジ、ピストンコアラー等で 海底地質分析を主とする。

(7) 海洋調查船（ROV（Remotely Operated Vehicle; 無人潜水艇), 有人潜水艇等を投入及び追尾して、 海底や海中の探查を行う。)

以上の調查船等に関する調查船等データベース を作成し、それを基にしたアンケート調査の実施に より、当該データベースの充実を図る。

\section{1 調查船等データベース作成}

調查船等データベースを構成する項目は以下の とおりである。

(1)「船舶」

船体スペック、搭載最大人数、推進器の種類、搭 載する観測機器及び揚貨装置能力等に関するデータ 項目から構成される。

(2)「乗組員」

職階別乗組員数と予備船員数に関するデータか ら構成される。

(3)「係留施設」

調査船等が常時係留されている岸壁に関するデー 夕から構成される。該当する日本版海図により係留
可能な最大岸壁長さ及び側傍水深の調査を行う。ま た、岸壁施設（補水・補油能力、上屋機能）や当該 調查船等が出動した期間中の他調査船等の係留の可 否についてアンケート調査を実施する。

Fig. 1 は、アンケート調査に添付寸る海図 ${ }^{(2)}$ の画 像データの一例であり、JAMSTEC 横浜基地の岸壁と その付近の海図において、対象調査船等の係留岸壁 を赤い線(移動して訂正可能)により表現している。

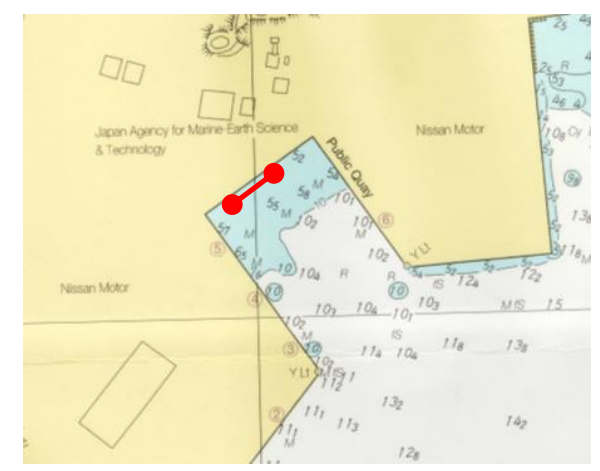

Fig. 1 Chart of JAMSTEC Yokohama base, and red line shows the estimated mooring position

（4）「運航実績」

調查船等の最大航続距離、運航海域、年間運航日 数及び運航時期のデータで構成される。

(5)「インセンティブ」

調査船等の本来業務（実習航海、訓練航海、海 洋調査等）以外に海洋観測・探査業務に参画するた めに必要とする人材・設備・資金及び環境等に関す る希望情報についてアンケート調查を実施する。必 要と想定される項目（船員（船員の人数）、燃料、食 料、人件費、観測機器）について複数選択、その他 必要とするものについて自由記入による回答を求め る。

\section{2 アンケート調查}

各調查船等の所有者に対して、公表資料を基に作 成したデータベース記載内容の確認及び不明項目の 追記とインセンティブについての回答を目的とした アンケート調査を実施する。

調査は電子メールを使用し、実施期間は 2016 年 8 月 1 日〜2016 年 8 月 31 日とし、 80 件を送信する。

\section{3. 研究結果}

実施したアンケート調查の回答は 49 件回収した。 回答を得られた機関の種類及び回答件数を Table 1 に示す。 
Table 1 Respondent organizations

\begin{tabular}{|l|c|}
\hline Respondent organization & $\begin{array}{l}\text { Number of } \\
\text { responses }\end{array}$ \\
\hline National organization & 24 \\
\hline Prefectural organizaton & 21 \\
\hline $\begin{array}{c}\text { Independent administrative } \\
\text { agency }\end{array}$ & 4 \\
\hline Total & 49 \\
\hline
\end{tabular}

49 件の調査船等については回答結果を加味し、デ 一タベースを作成した。アンケートの実施または回 収が不可能であった調査船等及び回答が得られなか った調査船等（53 隻）のデータベースについては公 表資料を基に作成したものを使用した。

以上のデータベースをまとめて修正調査船等デ ータベースとする。

\section{1 修正調査船等データベース}

Table 2 は、神戸大学大学院海事科学研究科付属 練習船深江丸 ${ }^{(3)}$ の一例である。そして、当該修正調 査船等データベースと回答結果を分析した。また、 各 Table 内に母数を $\mathrm{n}$ として示す。

Table 2 One data record written in Japanese

\begin{tabular}{|c|c|}
\hline 船名 & 深江丸 \\
\hline 竣工年月日 & $1987 / 10 / 14$ \\
\hline 船種 & 練習船 \\
\hline 船舶所有者 & 神戸大学 \\
\hline 船籍港 & 神戸 \\
\hline 総トン数 & 449 \\
\hline 国際総卜ン数 & 674 \\
\hline 全長 (m) & 49.95 \\
\hline 全幅 (m) & 10.0 \\
\hline 高さ (m) & 19.5 \\
\hline 喫水 $(m)$ & 3.75 \\
\hline 型深 (m) & 6.1 \\
\hline 最大速度 (ノット) & 14.28 \\
\hline 巡航速度 (ノット) & 12.5 \\
\hline 航続距離 (マイル) & 3,000 \\
\hline 航行区域 & $\begin{array}{c}\text { 近海区域 } \\
\text { (非国際) } \\
\text { A2水域 }\end{array}$ \\
\hline 資格 & 第4種船 \\
\hline 主機 & $\begin{array}{c}\text { ·4サイクルディーゼル機関 } 1,500 p \\
s \times 1\end{array}$ \\
\hline 使用燃料 & A重油 \\
\hline 推進器 & -4翼可変ピツチスキュープロペラ $\times 1$ \\
\hline 舵 & 1枚 \\
\hline 横移動装置 & $\begin{array}{l}\text { •バウスラスタ×1 } \\
\cdot \text { ·スタンスラスタ×1 }\end{array}$ \\
\hline 特殊操船装置 & ジョイスティツクコントロールシステム \\
\hline
\end{tabular}

Continuation of Table 2

\begin{tabular}{|c|c|}
\hline 観測機器 & $\begin{array}{l}\text { ·潮流計 } \\
\text { ·水温計 } \\
\text { ·音響測深機 } \\
\text { ·航海データ表示器 } \\
\text { ·統合航海情報処理表示装置 }\end{array}$ \\
\hline クレーン & $\begin{array}{c}\text { つり上げ最大荷重 } 0.95 \text { トン } \\
\text { ブーム長さ } 8 \mathrm{~m}\end{array}$ \\
\hline $\begin{array}{c}\text { 職階別乗組員数 } \\
\text { (人) }\end{array}$ & $\begin{array}{l}\text { 船長 } 1 \\
\text { 航海士 } 3 \\
\text { 機関長 } 1 \\
\text { 機関士 } 3 \\
\text { 部員 } 6 \\
\end{array}$ \\
\hline 予備員 (人) & なし \\
\hline 搭載最大人数 (人) & 64 \\
\hline $\begin{array}{c}\text { 係留可能岸壁長さ } \\
(\mathrm{m})\end{array}$ & 80 \\
\hline 測傍水深 (m) & 4.5 \\
\hline 海図データ & 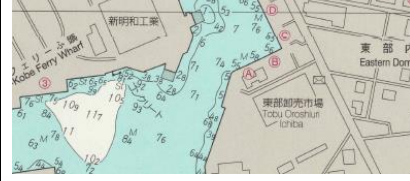 \\
\hline 係留場所 & $\begin{array}{c}\text { 兵庫県神戸市東灘区深江南町5- } \\
1-1 \\
\end{array}$ \\
\hline $\begin{array}{l}\text { 2016年度 } \\
\text { 運航予定 }\end{array}$ & $\begin{array}{l}\text { http://www.edu.kobe-u.ac.jp/gmsc- } \\
\text { fukaemaru/operation/H27.pdf }\end{array}$ \\
\hline 年間運航日数(日) & 125 \\
\hline 遠洋航海 & なし \\
\hline 遠洋航海寄港地 & なし \\
\hline
\end{tabular}

Table 3 Number of vessels by institution categories

\begin{tabular}{|l|c|}
\hline Institution category & $\begin{array}{c}\text { Number of } \\
\text { vessels }\end{array}$ \\
\hline JAMSTEC & 7 \\
\hline Japan Coast Guard & 5 \\
\hline Japan Fisheries Agency & 1 \\
\hline Japan Meteorological Agency & 2 \\
\hline $\begin{array}{l}\text { Japan agency of Maritime Education and } \\
\text { Training for Seafarers }\end{array}$ & 5 \\
\hline $\begin{array}{l}\text { Agency for Natural Resources } \\
\text { and Energy }\end{array}$ & 2 \\
\hline $\begin{array}{l}\text { Japan Fisheries Research and } \\
\text { Education Agency }\end{array}$ & 7 \\
\hline Prefectual Fisheries Research Institute & 24 \\
\hline National University & 17 \\
\hline College of National Institute Technology & 5 \\
\hline Fishery High School & 27 \\
\hline \multicolumn{1}{|c|}{ Total } & 102 \\
\hline
\end{tabular}


Table 4 Number of vessels by type categories

\begin{tabular}{|l|c|}
\hline Type Category & $\begin{array}{c}\text { Number of } \\
\text { vessels }\end{array}$ \\
\hline Academic research vessel & 6 \\
\hline Ecological research vessel & 1 \\
\hline Resource research vessel & 2 \\
\hline Ocean weather observation vessel & 2 \\
\hline Survey vessel & 5 \\
\hline Aquatic research vessel & 32 \\
\hline Fishery practice ship & 42 \\
\hline Training and practice ship & 12 \\
\hline Total & 102 \\
\hline
\end{tabular}

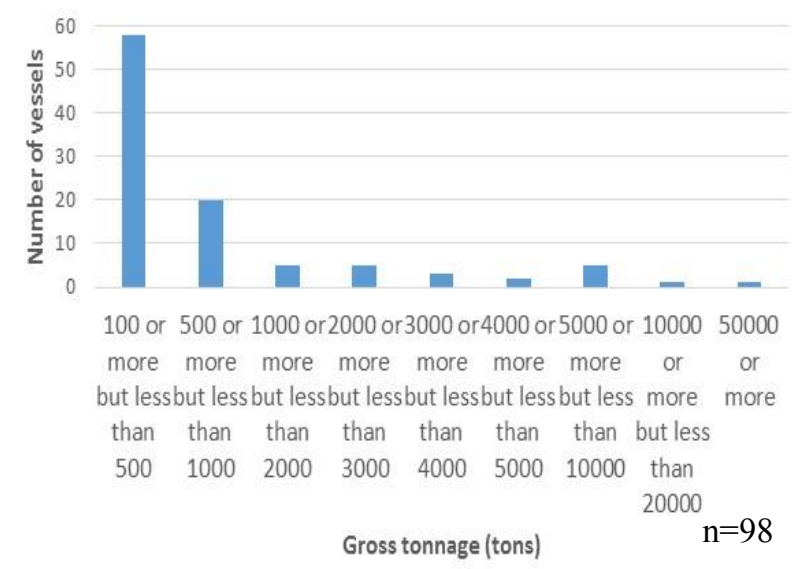

Fig. 2 Number of vessels by gross tonnage

（1）調査船等所有の機関カテゴリー別の隻数

修正調査船等データベースを構成する調査船等 を所有する国公立機関カテゴリー別の隻数を Table 3 に示す。水産系高等学校（27 隻）及び水産試験場

(24 隻) 所有の調査船等が半数を占めている。

(2) 調査船等種類カテゴリー別の隻数

調査船等の種類カテゴリー別隻数を Table 4 に示 す。水産系調查船（32 隻）及び水産系実習船・練習 船（42 隻）が約 8 割を占めている。

(3) 調査船等の総トン数別の隻数

調査船等における総トン数別の隻数を Fig. 2 に示 す。調査船等の半数以上が 100 トン以上 500 トン未 満である。

（4）運航年数別の調查船等の割合

運航年数別の調査船等の割合を Fig. 3 に示す。調 査船等の 6 割以上が船齢 19 年以下の船舶である。ま た、全体隻数の変動が少ないことと Fig. 3 に示す運 航年数の割合から、多くの調査船等が 30 年を上限と して代替新造が行われていることが推定できる。

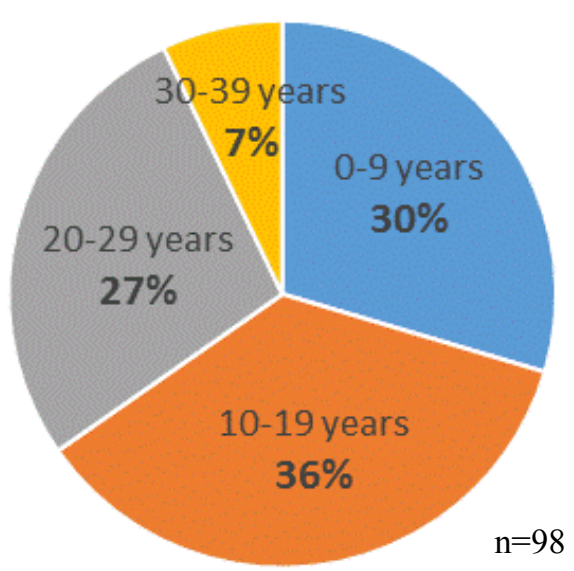

Fig. 3 Percentage of research vessels by age of operating

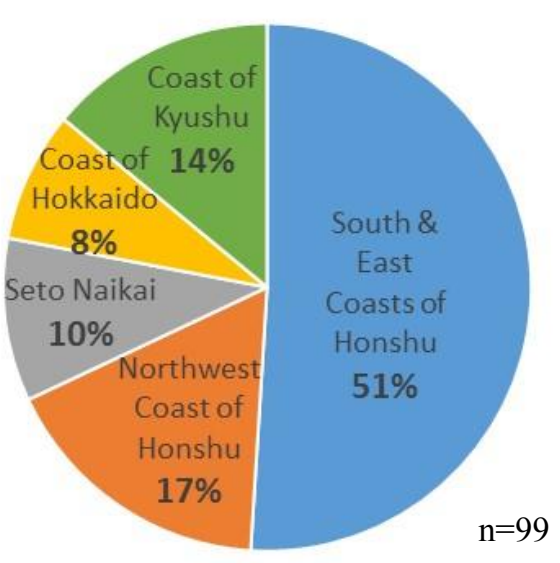

Fig. 4 Percentage regular quay by 5 areas following Japanese sailing directions

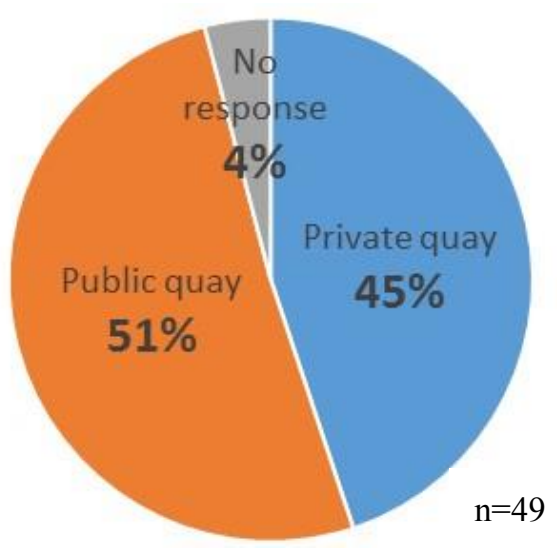

Fig.5 Percentage of private quay and public quay

（5）常用係留岸壁

各調査船等が通常使用する係留岸壁をもとに、日 本版水路誌に倣う 5 区域別割合を Fig. 4 に示す。調 査船等の存在が関東地区に集中しているため、本州 南・東岸の割合が半数を超えている。 


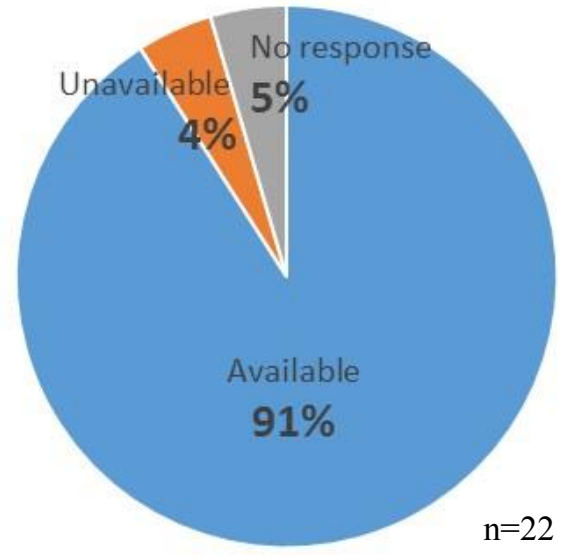

Fig.6 Propriety of use other research vessels on private Quay

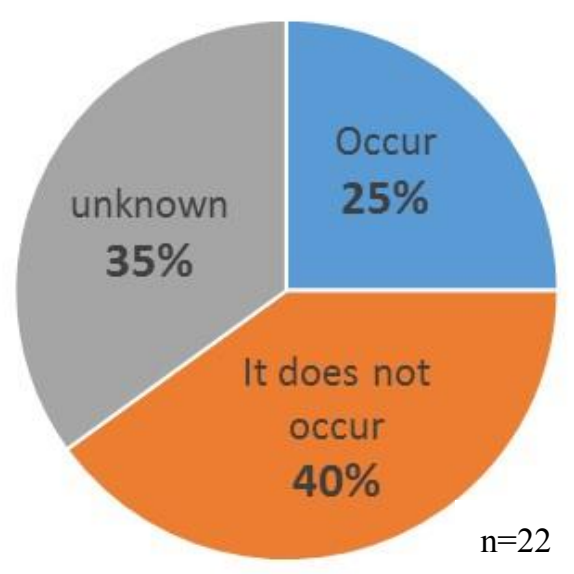

Fig.7 Percentage of quay usage fee incidence

\section{（6）専用岸壁または公共岸壁}

各調査船等が通常使用する係留岸壁における専 用岸壁または公共岸壁の割合を Fig. 5 に示す。約半 数が公共岸壁を使用している。

（7）他調查船等の係留の可否

専用岸壁所有船舶のうち、自船が出動中における 他調査船等の係留可否割合を Fig. 6 に示す。約 9 割 の岸壁において他調査船等の使用が可能である。

（8）岸壁使用料

専用岸壁を使用する調査船等のうち、当該岸壁の 他調査船等使用の場合における岸壁使用料発生の可 否割合をFig. 7 に示す。発生しない割合が一番多い が、他機関船舶の岸壁使用規定が無い等の理由によ り、発生不明である岸壁が 3 割以上存在する。

（9）専用岸壁における補給

専用岸壁において補給可能なものについての集 計結果をFig. 8 に示す。雑用水を除く 4 項目につい て約 8 割以上の岸壁で補給可能である。

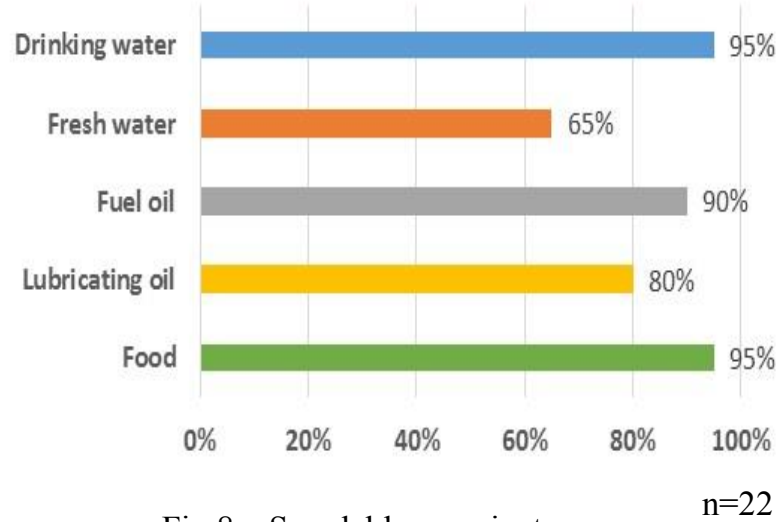

Fig.8 Supplable on private quay

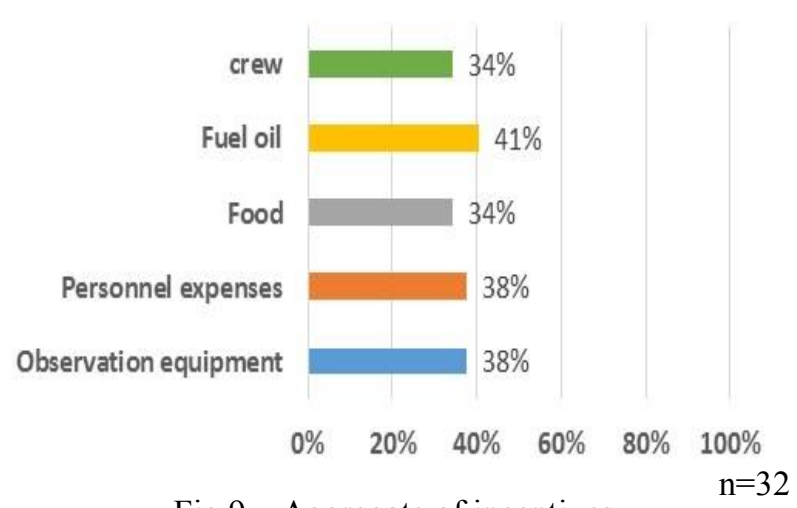

Fig.9 Aggregate of incentives

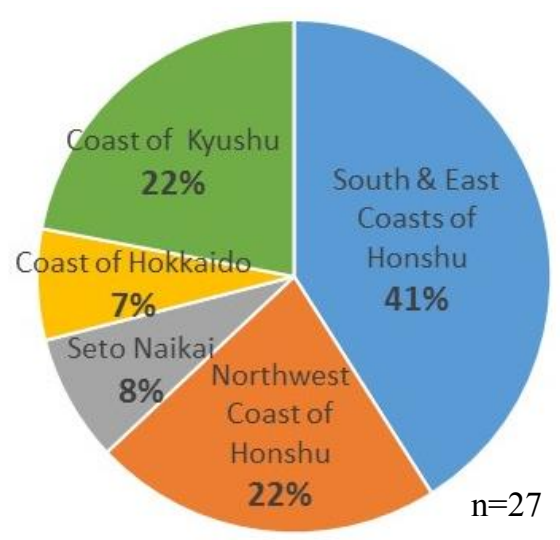

Fig.10 Percentage regular quay by 5 areas following Japanese sailing directions (Fishery High School)

(10）参画のためのインセンティブ

調査船等の本来業務（実習航海、訓練航海、海洋 調査等）以外に海洋観測・探査業務に参画するため に必要とする人材・設備・資金及び環境等に関する 希望情報についての集計結果を Fig. 9 に示す。燃料 の割合が一番多いが、全ての項目において 3 割〜 4 割の調査船等が希望した。その他必要とするものに ついては「他船との船員の融通」「観測機器の設置」 が挙げられた。 


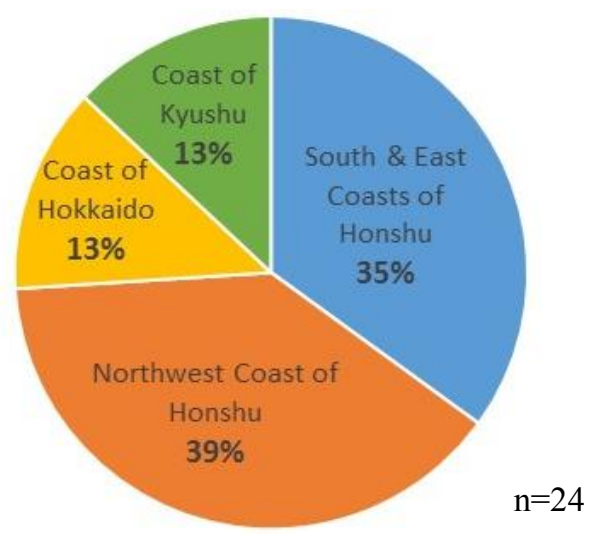

Fig.11 Percentage regular quay by 5 areas following Japanese sailing directions (Prefectual Fisheries Research Institute)

Apr. May Jun. Jul. Aug. Sep. Oct. Nov.Dec. Jan. Feb. Mar.

\begin{tabular}{|c|c|c|c|c|c|c|c|c|}
\hline A & & & & & & 60days & & 60days \\
\hline B & \multicolumn{3}{|c|}{} & \multicolumn{2}{|c|}{} & & total 173days & \\
\hline C & & & & & & \multicolumn{3}{|c|}{ 50days } \\
\hline D & & & & & & \multicolumn{2}{|c|}{ 70days $\times$ 2voyage } \\
\hline E & & & & & & 73days & & 73days \\
\hline F & & \multicolumn{3}{|c|}{ 70days } & & 70days & & 70days \\
\hline
\end{tabular}

Fig.12 An ocean voyage term and number of days in FY2016

\section{2 水産系高等学校及び水産試験場}

半数を占める水産系高等学校及び水産試験場所有 の調査船等についての集計結果を以下にまとめる。

（1） 水産系高等学校調査船等の総トン数

水産系高等学校が所有する調査船等の総トン数 は平均 488.1 トンであり、ほとんどの調査船等が年 に数回の遠洋航海を行っていることが運航実績上の 特色となっている。一方、水産試験場が所有する船 舶の総トン数は平均 180.6 トンであり、主に試験場 所在地付近の沿岸を対象に漁業資源を中心とした海 洋調査を実施している。

(2) 区域別隻数割合

水産系高等学校及び水産試験場所有調査船等の 日本版水路誌に倣う 5 区域別隻数割合を Fig. 10、 Fig. 11 に示す。特に、多くの臨海都道府県水産試験 場が所有する調査船等については、その存在する区 域の偏りが少ないことがわかる。

(3) 運航計画及びその日数

平成 28 年度の遠洋航海を実施する水産系高等 学校所有調査船等のうち、寄港地がホノルルである 6 隻の運航計画及びその日数を Fig. 12 に示す。B は
4 月〜 7 月、 9 月〜 12 月及び 1 月〜 3 月にかけて遠 洋航海実施し、その 3 航海の合計日数は 173 日であ ることを示している。年度の後半にあたる 9 月〜 3 月にかけて遠洋航海を実施する調査船等が多く、1 学期にあたる 4 月〜 7 月に遠洋航海を実施しない調 査船等が存在した。また、遠洋航海の外国寄港地は ホノルルが一番多く、国内寄港地については那覇、 神戸の回答が 1 隻ずつ存在した。

\section{4. 情報共有ネットワーク}

日本国内における海洋観測に関するデータ共有 システムは以下のものが存在する。

(1) 海洋情報クリアリングハウス ${ }^{(4)}$

海洋情報の概要・入手方法等をデータベース化し、 インターネットを通じて提供するシステム。システ ムは海上保安庁が管理する。

(2) 海洋気象観測船による観測資料の公開 ${ }^{(5)}$

気象庁所有の 2 隻の海洋観測船による海洋・気象 観測等の情報を公開している。

(3) $\operatorname{FRESCO}^{(6)}$

水産研究所及び水産試験場における漁獲情報・海 洋情報の集約・共有するシステム。

\section{5. 調査船等運航ネットワークの提案}

調査船等運航ネットワーク実現に向け、以下のこ とを提案する。

（1）調査・観測データの共有

前章に述べたデータ共有・公開システムに加え、 各調査船等が行う海洋観測データの共有化を目指す。

海上保安庁管理の海洋情報や気象庁管理の海 洋・気象観測等情報および水産研究所及び水産試験 場の漁獲情報・海洋情報は、監督省庁が異なりデー タの使用目的や管理方法が異なるために、データの 統合には大きな障壁が残るが、海洋に関する貴重な データをより有効に利用するためには、それらの統 合は不可避の問題である。

（2）本来業務に並行・付加する調査・観測

例えば、船尾のAフレームクレーン（観測機器の 曳航や海中投下用クレーン）および地磁気観測装置 未装備の商船系練習船にポータブル型の観測機器を 特定の航海に設置し、航海訓練海域での調査活動を 実施する。具体例として、神戸大学所有の練習船深 江丸（Aフレームクレーン・地磁気観測装置未装備 船）に地磁気測定装置を臨時で設置し、南海トラフ 北方一部海域の地磁気測定を行ったという事例があ 
り、この手法を適用することにより、商船系練習船 の運航ネットワーク構築が可能となる。また、その ためには、ポータブル型観測機器を収納するコンテ ナの規格化が重要となる。数種類の規格を策定する ことにより、各調查船等の搭載スペース及びクレー ン能力（つり上げ最大荷重とブーム長さ）により、 収納コンテナの取捨選択が可能となる。また、規格 化されたコンテナ固縛装置の上甲板等への設置も可 能となる。

（3） 本来業務以外の時期に追加して調查・観測のた めの航海の実施

3. 1(10)参画のためのインセンティブで記述した とおり、現在、調查船等における本来業務遂行のた めの運航予算と人員及び時間が潤沢ではない状況等 により、本来業務以外の時期に追加して海洋観測・ 調査を実施することは極めて困難である。しかしな がら、インセンティブ等を充実して参画しやすい環 境整備を行っていけば、調査船等運航ネットワーク が構築され、日本の海洋観測・探査が大きく前進す るものと考える。

（4）水産系ネットワークと調查船等運航ネットワ 一クの連携

修正調查船等データベースを構成する調查船等 の半数である 51 隻の水産系高等学校及び水産試験 場の水産系調查船等は、偏在することなく全国臨海 部に配置され、水産資源の調查と捕獲を目的とする 全国水産系ネットワークを構成している。当該ネッ トワークの特徴は、広範囲の水域の水温や海潮流等 の観測とデータの共有が可能である点である。水産 系調查船等が調查船等運航ネットワークに直ちに参 画することは現状では困難である。しかしながら、 ポータブル型観測機器の開発やインセンティブ等を 充実して参画しやすい環境整備を行っていけば、水 産系ネットワークを包含する調查船等運航ネットワ ークが構築され、日本の海洋観測・探査が大きく前 進するものと考える。また、将来的には総トン数 100 トン未満の全国水産系ネットワークの船舶も調查船 等運航ネットワークとの連携構築で、より詳細な海 域の観測データの取得が可能となろう。一方で、全 国の水産試験場間では調查船等の共同運航を目指し たネットワーク構築の動きがあり、既に、観測デー タの集約・共有の水産試験場ネットワーク FRESCO が構築されているので、観測船等運航ネットワーク との今後の連携が不可欠となろう。

\section{6. 今後の展望}

年間に一航海のスポットでも参画できる調査船 等の数が増え、そのような運航情報と海洋観測・探 查の成果が社会に喧伝されれば、それらは資源小国 である日本国民の耳目を惹き、日本の海洋観測・探 查の機運を高揚することが期待できる。同時に提案 する修正調查船等データベースを適宜更新及び充実 させていくことは、今後の日本の海洋観測・探査を 推進していくうえで不可欠であると考える。また、 ポータブル型観測機器のユニット化は、観測機器の 供用化と全国展開が可能となり、副産物として観測 データの均質化も実現できる。

一例として、乗組員の融通に関しても、本来の所 属機関之融通先の機関が行政上異なる組織であれば、 雇用に関して問題が発生する。そのためにも国政の ガバナンスが不可欠であり、国・地方および省庁間 の行政協力が必要となる。日本の領海および EEZを 守り、有効活用寸るためには、日本国全体で対応す ることが肝要である。

今後は、関東圈で海洋底探査ネットワークの構築 を目指している公益財団法人日本海洋科学振興財団 及び JAMSTEC と連携しながら、UNOLS との比較、検 討を含め、日本国内の国公立機関が保有する調查船 等運航ネットワークの構築を推進する。また、供用 化を目指した海洋観測機器のユニット化と管理方法 について研究を継続する。

\section{謝辞}

本論文を作成するにあたり、アンケート調査にご 協力いただきました各機関の皆様に深甚なる感謝の 意を表します。

\section{参考文献}

(1) University-National Oceanographic Laboratory System: WHAT IS UNOLS?, https://www. unols. org/what-unols, 2016. 8. 9.

（2）海上保安庁：日本版海図，JP1083 Yokosuka Ko Yokosuka, 2015. 10.

（3）神戸大学大学院海事科学研究科 : 深江丸につい $\tau$, http://www. edu. kobe-u. ac. jp/gmsc-fukae maru/, 2016. 8.9.

（4）海上保安庁: 海洋情報クリアリングハウス（マ リンページ), http://www. mich. go. jp/contac t. htm, 2017.3. 20. 
（5）気象庁：海洋気象観測船による海洋・海上気象 観測資料, http://www. data. jma. go. jp/kaiyou /db/vesse1_obs/data-report/html/ship/ship .php, 2017.3. 20.

（6）FUJITSU: 水産資源評価情報システム FRESCO, http://www. fujitsu. com/downloads/JP/ archive/img.jp/jmag/vo153-1/paper17. pdf, 2016. 8. 5. 